\title{
Evaluation of dampness-induced strength reduction of calcium silicate blocks
}

\author{
Halina Garbalińska ${ }^{1, *}$, Anna Głowacka ${ }^{2}$, and Jarosław Strzałkowski ${ }^{1}$ \\ ${ }^{1}$ Department of Building Physics and Building Materials, Faculty of Civil Engineering and Architecture, \\ West Pomeranian University of Technology Szczecin, al. Piastów 50, 70-311 Szczecin, Poland \\ ${ }^{2}$ ARIKON Hoch- und Ingenierbau GmbH/Building construction and civil engineering, Komturstrasse $18 \mathrm{~A}$, \\ 12099 Berlin, Germany, http://www.arikon.de/kontakt.html
}

\begin{abstract}
Due to its numerous technical advantages as well as health benefits, sand-lime brick is increasingly used in the construction of brick walls, especially in residential buildings. Unfortunately, the occurrence of damp leads to a sharp deterioration of the technical properties of the material and the environmental conditions inside the building. Given the importance of this issue, an attempt was made to diagnose the extent of dampness variability of the main hygrothermal and strength characteristics of calcium silicate products. The study involved the basic material properties (density in dry and water-saturated conditions), moisture-related properties (capillary adsorption coefficient and sorptivity), thermal coefficients (thermal conductivity and volumetric heat capacity) as well as mechanical properties (compressive strength). This article describes diagnostic studies that were conducted to assess the extent of the effect of dampness on the strength of sand-lime products. In order to render the diagnosis more comprehensive and to include a wider range of silicate blocks available on the market, it was decided to examine three groups of silicate blocks (strength class 15, 20 and 25) obtained from three different factories. It was demonstrated that for all the examined groups dampness caused a significant decrease in compressive strength ranging from about $30 \%$ to about $40 \%$.
\end{abstract}

\section{Introduction}

An assessment included in [1] of the domestic market of wall construction materials indicates a progressive sales growth in the period of 2013-2016. This increasing demand has been maintained both in the case of housing development for sale and rent as well as single-family housing. In the Polish market, the three most popular wall construction materials are: autoclaved aerated concrete, ceramic brick and calcium silicate brick. Their percentages of wall material market shares in 2016 were, respectively, $38.1 \%, 30.0 \%$ and $14.7 \%$.

In [2], a comparison was made of the mentioned most popular wall materials using a multi-criteria techno-economic analysis. The evaluation took the following into account: cost, compressive strength, environmental safety, sound insulation and heat accumulation.

\footnotetext{
* Corresponding author: Halina.Garbalinska@zut.edu.pl
} 
Out of the three material groups, the highest compressive strength was determined for silicate blocks. According to the manufacturers' websites, they are characterised by compressive strength ranging from $15 \mathrm{MPa}$ to $25 \mathrm{MPa}$, while higher-class custom-made blocks can also be produced [3].

Manufacturers of building materials usually provide technical characteristics only for dry condition. However, with the increase in dampness, most of the properties tend to get worse significantly.

In order to diagnose the extent to which dampness affects the properties of calcium silicate products, comprehensive diagnostic tests were conducted within the work [4]. They involved the basic material properties (density in dry and water-saturated condition), dampness properties (capillary adsorption coefficient and sorptivity), thermal properties (thermal conductivity and volumetric heat capacity) as well as compressive strength. The results of capillary sorption are given in [5], and the results of heat measurement are included in [6]. This article, in turn, presents the results of strength tests.

\section{Description of the strength tests and the obtained results}

The evaluation included three groups of calcium silicate products from different manufacturers. These were Efekt (strength class 15), Xella (strength class 20) and Barlinek (strength class 25) silicate blocks.

Water was introduced into the tested samples by means of the capillary action mechanism which resulted in different water vertical distribution throughout the tested samples. The study consisted in a laboratory reproduction of a situation in which the wall element of the exterior partition is exposed to direct and prolonged contact with water.

Six samples from each manufacturer were placed vertically in trays filled with water so that their end surface was the absorption surface. During the study, water was added regularly to maintain its level at the height of approx. $2 \mathrm{~mm}$ measured from the bottom of the sample. Initially, the samples quickly absorbed the water. Over time, the absorption rate decreased significantly. The process of water absorption continued for six weeks. At the end of this period, all the samples were collected from the trays and cut at mid-height (Figure 1).

Then, the upper samples (1) were dried to constant weight in a laboratory dryer by gradually raising the temperature: $40^{\circ} \mathrm{C} \rightarrow 70^{\circ} \mathrm{C} \rightarrow 105^{\circ} \mathrm{C}$. The bottom samples (2) were placed in a water bath where they were kept until full saturation.

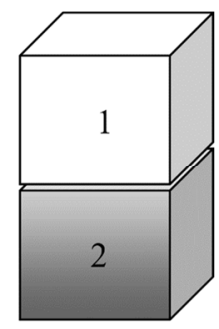

Fig. 1. Division of the silicate block into half-samples.

The strength tests of silicate wall elements involved 6 upper half-samples in dried condition and 6 water-saturated bottom half-samples of each batch. The samples surfaces were not subjected to any further treatment. In all cases, the surfaces were flat and did not feature any significant irregularities. According to the measurements, the difference in height along the length of the sample did not exceed $1 \mathrm{~mm}$. The dimensions of the two pressure plates were larger than the largest dimension of each of the samples. First, 
the samples dried to constant-weight were tested in terms of their compressive strength. Subsequently, similar tests were carried out on the water-immersed samples. The view of the test stand is shown in Figure 2.

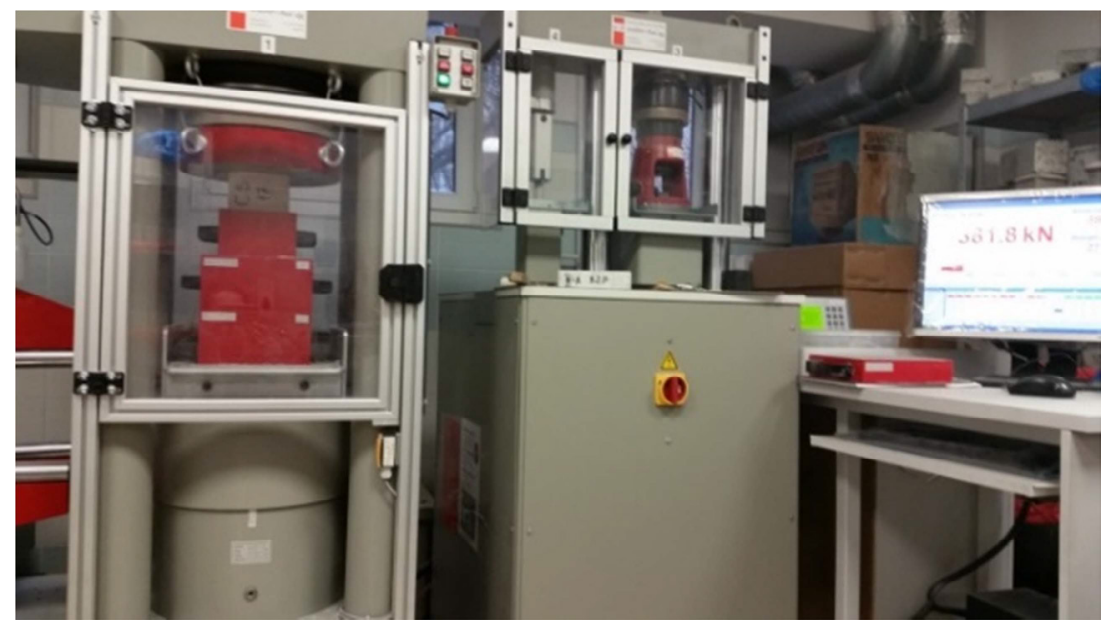

Fig. 2. Stand for compressive strength testing of half-samples.

Throughout the examination, the maximum load for each half was recorded and its strength was calculated by dividing the obtained compression force $[\mathrm{kN}]$ by the loaded surface area $\left[\mathrm{mm}^{2}\right]$. For each sample, the surface area was determined on the basis of individually specified geometrical dimensions. The results obtained in the tests are summarized in Table 1.

Table 1. Results obtained in compressive strength tests for dry and water-saturated samples.

\begin{tabular}{|c|c|c|c|c|c|c|c|}
\hline \multicolumn{2}{|c|}{ Sample } & $\begin{array}{c}\text { Compressive } \\
\text { strength of } \\
\text { dry samples } \\
\text { [MPa] }\end{array}$ & $\begin{array}{c}\text { Coefficient } \\
\text { of variation } \\
{[\%]}\end{array}$ & $\begin{array}{c}\text { Average } \\
\text { compressive } \\
\text { strength of } \\
\text { dry samples } \\
\text { [MPa] }\end{array}$ & $\begin{array}{c}\text { Compressive } \\
\text { strength of } \\
\text { wet samples } \\
\text { [MPa] }\end{array}$ & $\begin{array}{c}\text { Coefficient } \\
\text { of } \\
\text { variation } \\
{[\%]}\end{array}$ & $\begin{array}{c}\text { Average } \\
\text { compressive } \\
\text { strength of } \\
\text { wet samples } \\
\text { [MPa] }\end{array}$ \\
\hline \multirow{6}{*}{$\underbrace{\frac{\vec{d}}{d}}_{\square=}$} & CS-1 & 26.4 & \multirow{6}{*}{12.3} & \multirow{6}{*}{26.6} & 18.1 & \multirow{6}{*}{8.3} & \multirow{6}{*}{17.8} \\
\hline & CS-2 & 26.3 & & & 18.3 & & \\
\hline & CS-3 & 28.4 & & & 18.2 & & \\
\hline & CS-4 & 24.9 & & & 16.8 & & \\
\hline & CS-5 & 27.5 & & & 18.3 & & \\
\hline & CS-6 & 26.3 & & & 17.1 & & \\
\hline \multirow{6}{*}{$\frac{\stackrel{\pi}{\sigma}}{\overline{\vec{J}}}$} & CS-9 & 34.4 & \multirow{6}{*}{29.4} & \multirow{6}{*}{34.8} & 20.0 & \multirow{6}{*}{15.5} & \multirow{6}{*}{22.0} \\
\hline & CS-10 & 41.1 & & & 21.8 & & \\
\hline & CS-12 & 29.0 & & & 21.7 & & \\
\hline & CS-13 & 35.3 & & & 23.2 & & \\
\hline & CS-14 & 36.8 & & & 21.6 & & \\
\hline & CS-16 & 32.5 & & & 23.7 & & \\
\hline \multirow{6}{*}{ : } & CS-17 & 36.4 & \multirow{6}{*}{16.7} & \multirow{6}{*}{39.6} & 25.7 & \multirow{6}{*}{12.3} & \multirow{6}{*}{27.3} \\
\hline & CS-18 & 41.6 & & & 27.0 & & \\
\hline & CS-20 & 34.9 & & & 27.9 & & \\
\hline & CS-22 & 41.9 & & & 26.6 & & \\
\hline & CS-23 & 41.4 & & & 29.3 & & \\
\hline & CS-24 & 41.2 & & & 27.1 & & \\
\hline
\end{tabular}


Table 1 presents the adopted labels for the samples grouped by manufacturer, i.e. Efekt, Xella, Barlinek. In addition, within each product line samples were divided into two humidity states, i.e. samples dried to constant weight (marked 'dry'), and samples saturated with water (marked as 'wet'). Each of the 36 samples (18 dry and 18 water-saturated) was measured for its compressive strength $f_{c i}$ rounded to the nearest $0.1 \mathrm{~N} / \mathrm{mm}^{2}$. Additionally, for each of the 6 groups of samples the coefficient of strength variation and the average compressive strength $f_{c}$ were calculated.

\section{Analysis of the results of strength tests in terms of the influence of dampness and microstructure}

In order to visualize the obtained results, an overview is presented in Figure 3.

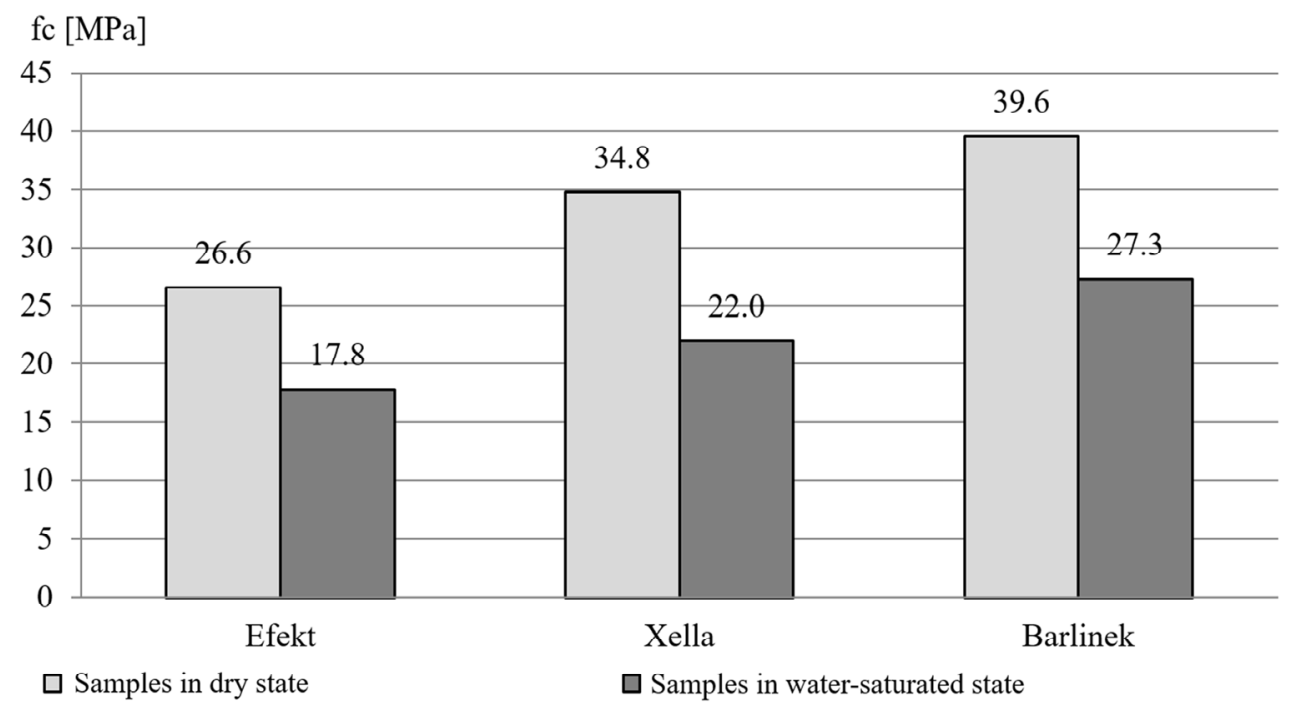

Fig. 3. Overview of the average values of compressive strength of individual groups of silicate blocks in dry and water-saturated state.

The overview visualizes the differences in the values of strength properties obtained for two cases when the tested material was subjected to destructive forces while being in dry or water-saturated state.

In each product group, a definite decreasing trend in compressive strength as the result of water saturation of samples was observed. At saturation, the average strength of the Efekt, Xella and Barlinek blocks was, respectively, 0.67, 0.63 and 0.69 of the average strength value in dry state.

It is common knowledge that the properties of given materials are determined by their internal structure and arrangement of pores, particularly those which can be filled with water in the liquid phase, cf. [7-10].

Table 2 lists the values of apparent density and moisture content by weight and volume specified for individual water-saturated blocks. 
Table 2. Data on water sorptivity by weight and volume and apparent density - determined on the basis of saturated half-samples.

\begin{tabular}{|c|c|c|c|c|c|c|c|}
\hline & imple & $\begin{array}{c}\text { Absorptivity by } \\
\text { weight } \\
\mathbf{n}_{\mathrm{w}}=\left[\left(\mathrm{m}_{\mathrm{n}}-\mathbf{m}\right) / \mathbf{m}\right] \cdot 100\end{array}$ & $\begin{array}{c}\text { Average } \\
\mathbf{n}_{\mathbf{w}}\end{array}$ & $\begin{array}{c}\text { Absorptivity by } \\
\text { volume } \\
\mathbf{n}_{\mathrm{v}}=\left[\left(\mathrm{m}_{\mathrm{n}}-\mathrm{m}\right) / \mathrm{V}\right] \cdot 100\end{array}$ & $\underset{\mathbf{n}_{\mathbf{v}}}{\text { Average }}$ & $\begin{array}{c}\text { Apparent } \\
\text { density } \\
\rho_{\mathrm{p}}=\mathbf{n}_{\mathrm{v}} / \mathbf{n}_{\mathrm{w}}\end{array}$ & Average \\
\hline & CS-1 & 13.6 & & 25.0 & & 1.836 & \\
\hline & $\mathrm{CS}-2$ & 12.7 & & 23.6 & & 1.858 & \\
\hline$\frac{\pi}{0}$ & CS-3 & 14.2 & & 26.0 & & 1.836 & \\
\hline 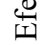 & CS-4 & 13.6 & 13.4 & 24.8 & 24.7 & 1.825 & 1.840 \\
\hline & CS-5 & 13.1 & & 24.2 & & 1.839 & \\
\hline & CS-6 & 13.3 & & 24.6 & & 1.848 & \\
\hline & CS-9 & 18.0 & & 29.5 & & 1.640 & \\
\hline & CS-10 & 15.8 & & 26.4 & & 1.674 & \\
\hline$\cong$ & CS-12 & 20.1 & & 32.2 & & 1.600 & \\
\hline $\bar{x}$ & CS-13 & 20.5 & 18.8 & 33.4 & 30.7 & 1.627 & 1.638 \\
\hline & CS-14 & 17.2 & & 28.5 & & 1.664 & \\
\hline & CS-16 & 21.2 & & 34.3 & & 1.622 & \\
\hline & \begin{tabular}{|l} 
CS-17 \\
\end{tabular} & 15.1 & & 27.3 & & 1.810 & \\
\hline & CS-18 & 14.5 & & 26.6 & & 1.831 & \\
\hline. & CS-20 & 18.3 & & 32.2 & & 1.755 & \\
\hline$\overline{\bar{E}}$ & CS-22 & 13.6 & 14.3 & 24.9 & 26.1 & 1.829 & 1.830 \\
\hline & CS-23 & 10.3 & & 19.8 & & 1.922 & \\
\hline & CS-24 & 14.1 & & 25.9 & & 1.834 & \\
\hline
\end{tabular}

The comparative analysis of the data collected indicates that products Efekt and Barlinek have similar weight and volume water sorptivity and apparent density values. The resultant values are respectively: $n_{w}=13.4 \%$ and $14.3 \%, n_{v}=24.7 \%$ and $26.1 \%, \rho_{p}=1.840 \mathrm{~kg} / \mathrm{dm}^{3}$ and $1.830 \mathrm{~kg} / \mathrm{dm}^{3}$. On the other hand, their strength properties are placed at two opposite sides. The Efekt products show clearly the lowest, and the Barlinek products definitely the highest, compressive strength. For Efekt, Xella and Barlinek these relationships are the following: $f_{c, \text { dry }}=26.6 \mathrm{MPa}<34.8 \mathrm{MPa}<39.6 \mathrm{MPa}$ oraz $f_{c, \text { wet }}=17.8 \mathrm{MPa}<22.0 \mathrm{MPa}<27.3 \mathrm{MPa}$.

The determined values and relationships prove that the density and sorptivity do not carry any useful information on the basis of which one could predict their potential strength characteristics.

To further clarify the differences in the porosity structure of separate groups of silicate blocks, complementary microstructural tests were carried out with the use of mercury porosimetry. Figure 4 shows the differential curves of pore distribution recreated for each of the tested materials. 


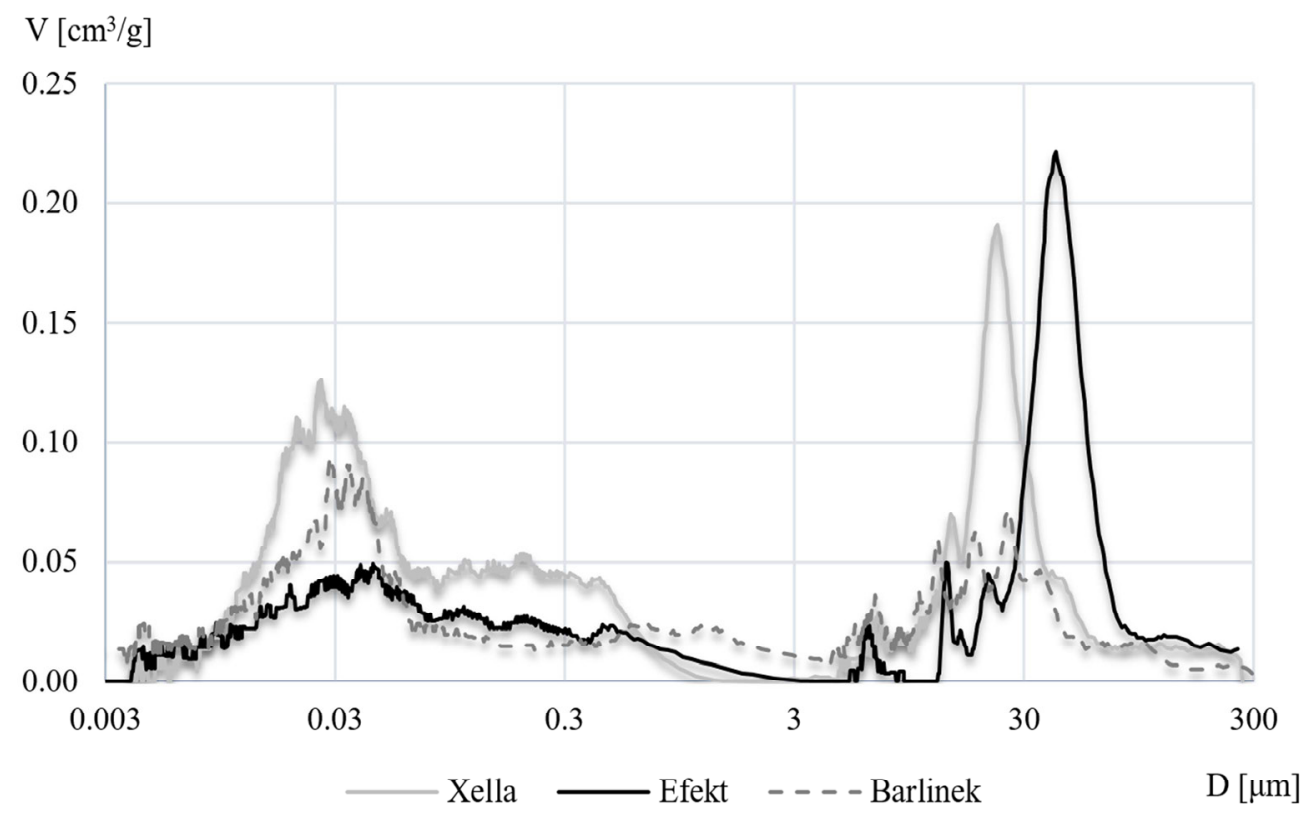

Fig. 4. Differential curves of pore distribution in the three tested silicate bricks: Xella, Efekt, Barlinek.

\section{Conclusion}

The obtained results of strength tests carried out on silicate blocks in dry and watersaturated state indicate a definite downward trend in compressive strength as the result of water-saturation of the pores.

The obtained quantitative relationships in case of each material were similar: Efekt: $f_{c, w e t} / f_{c, d r y}=0.67$, Xella: $f_{c, w e t} / f_{c, d r y}=0.63$, Barlinek: $f_{c, w e t} / f_{c, d r y}=0.69$.

The collected results point to the similar extent of mechanical destruction in each of the tested strength classes. In the case of the Efekt silicate blocks (strength class 15), Xella blocks (strength class 20), and Barlinek blocks (strength class 25) alike the decrease in strength was significant and exceeded $30 \%$.

For individual products, these relationships were the following:

- Efekt: $f_{c, d r y}=26.6 \mathrm{MPa} \rightarrow f_{c, w e t}=17.8 \mathrm{MPa}$,

- Xella: $f_{c, d r y}=34.8 \mathrm{MPa} \rightarrow f_{c, w e t}=22.0 \mathrm{MPa}$,

- Barlinek: $f_{c, d r y}=39.6 \mathrm{MPa} \rightarrow f_{c, \text { wet }}=27.3 \mathrm{MPa}$.

It is worth emphasizing that this issue is very important in technical terms, since a sharp deterioration in mechanical properties due to heavy dampness occurs mainly in the case of the lower parts of the wall which are exposed to groundwater or, e.g., flood water. The lower parts of the walls bear much more load than the upper floor walls and therefore they have to function at a much higher stress level. As a result, even a slight decrease in strength caused by dampness can endanger the safety of the whole structure.

Our studies also point to the influence of specific internal structure of the silicate blocks on their mechanical properties. Relationships between the compressive strength values of the three groups of products were analysed considering their microstructural properties. It was clearly demonstrated that conclusions about the potential strength capabilities cannot be drawn on the basis of data on apparent density and water sorptivity by weight and volume. The test results imply that it is not the total amount of pores but their specific geometry that is crucial. The higher the number of small-diameter pores in the material, the 
greater the strength of the material. Contrastingly, larger capillary pores and air voids are proved to have the most negative influence on the strength properties. The analysis of pores from $3 \mu \mathrm{m}$ up to $300 \mu \mathrm{m}$ proves that the Efekt, Xella and Barlinek blocks have the highest, lower and the lowest number of pores respectively. This directly influences the macro-scale diagnosed relationships of strength: $f_{\text {Efekt }}<f_{\text {Xella }}<f_{\text {Barlinek }}$.

\section{References}

1. L. Misiewicz, Krajowy rynek materiatów budowlanych do wznoszenia ścian $w 2016 r$., Materiały Budowlane 536, 2-3 (2017) (in Polish)

2. R. Dachowski, P. Kostrzewa, Silikaty $w$ świetle ekologii i ekonomii, Budownictwo o zoptymalizowanym potencjale energetycznym 19, 41-46 (2017) (in Polish)

3. http://www.grupasilikaty.pl/zalety-silikatow.php (access: 16.03.2018)

4. A. Głowacka, Badanie $i$ analiza podstawowych parametrów technicznych cegły silikatowej narażonej na oddziaływanie wody kapilarnej, engineering diploma thesis, carried out under the supervision of H. Garbalińska, West Pomeranian University of Technology Szczecin (2016) (in Polish)

5. H. Garbalińska, A. Głowacka, Symulacyjne badania dotyczace rozprzestrzeniania się zawilgocenia kapilarnego $w$ ścianach z bloczków silikatowych, Polska Energetyka Słoneczna 43, 55-58 (2015) (in Polish)

6. H. Garbalińska, A. Głowacka, Ocena wilgotnościowej zmienności przewodności cieplnej bloczków silikatowych pochodzących z różnych wytwórni, Polska Energetyka Słoneczna 43, 59-62 (2015) (in Polish)

7. H. Garbalińska, A. Wygocka, Microstructure modification of cement mortars: Effect on capillarity and frost-resistance, Constr. Build. Mater. 51, 258-266 (2014)

8. A. Wygocka, H. Garbalińska, Assessment of scale of the microstructure impact on capillary transport in cement-based composites with polypropylene fibers, Edited by: Mahdavi, A; Martens, B, Conference: 2nd Central European Symposium on Building Physics Location: Vienna Univ Technol, Vienna, Austria Date: SEP 09-11, 2013, Sponsor(s): Dept Bldg Phys \& Bldg Ecol, Contributions to Building Physics, 83-86 (2013)

9. J. Strzałkowski, H. Garbalińska, Thermal and strength properties of lightweight concretes with the addition of aerogel particles, Adv. Cem. Res. 28, 567-575 (2016)

10. J. Strzałkowski, H. Garbalińska, Porosimetric, Thermal and Strength Tests of Aerated and Nonaerated Concretes, Book Group Author(s): IOP Conference: World Multidisciplinary Civil Engineering-Architecture-Urban Planning Symposium (WMCAUS) Location: Prague, Czech Republic Date: JUN 12-16, 2017, Book Series: IOP Conference Series-Materials Science and Engineering 245, Article Number: UNSP 032017 (2017) 